\title{
HUBUNGAN KADAR HEMOGLOBIN DAN DENYUT NADI ISTIRAHAT TERHADAP KAPASITAS AEROBIK SISWA SMKN 58 JAKARTA YANG MENGIKUTI EKSTRAKURIKULER FUTSAL
}

\author{
Jamil Hudin Amanuloh ${ }^{1}$, \\ dr. Ruliando Hasea Purba, MARS, SpRM², Dr. Yasep Setiakarnawijaya, \\ SKM, M.Kes ${ }^{2}$ \\ ${ }^{1}$ Program Studi Ilmu Keolahragaan \\ ${ }^{2}$ Fakultas Ilmu Keolahragaan Universitas Negeri Jakarta, Kampus B, Jakarta
}

\begin{abstract}
Abstrak: Penelitian ini bertujuan untuk mengetahui hubungan anţara Kadar Hemoglobin dan Denyut Nadi Istirahat Terhadap Kapasitas Aerobik baik secara sendiri-sendiri maupun bersama-sama. Penelitian dilakukan di laboratorium Klinik Mulya Farma, Setu Cipayung, Bambu Apus Jakarta Timur pada tanggal 13 dan 21 September 2012. Penelitian menggunakan metode survey dengan teknik korelasi, sampel adalah siswa SMK N 58 Jakarta yang mengikuti ekstrakurikuler futsal. Pengambilan sampel dengan menggunakan purposive sampling. Dari keseluruhan yang mengikuti ekstrakurikuler futsal diambil 18 orang untuk dijadikan sampel yang berdasarkan ciri-ciri, sifat-sifat dan karakteristik tertentu. Teknik pengujian hipotesis dilakukan dengan menggunakan teknik analisis statistik korelasi sederhana dan korelasi ganda yang dilanjutkan dengan uji-t pada taraf signifikan $\alpha=0,05$. Hasil penelitian menggambarkan pertama, terdapat hubungan yang signifikan antara Kadar Hemoglobin terhadap Kapasitas Aerobik, dengan persamaan garis regresi linear $\tilde{Y}=15,32+$ $0,69 \mathrm{X} 1$, koefisien korelasi (ry1) $=0,69$ dan koefisien determinasi $\left(\mathrm{ry}^{2}\right.$ ) $=0,4761$, yang berarti variable Kadar Hemoglobin memberikan sumbangan terhadap Kapasitas Aerobik sebesar 47,61\%. Kedua, terdapat hubungan yang signifikan antara Denyut Nadi Istirahat terhadap Kapasitas Aerobik, dengan persamaan garis regresi linear $\tilde{Y}=14,07+0,72 \mathrm{X}_{2}$, koefisien korelasi $($ ry2 $)=0,71$ dan determinasi $\left(\mathrm{ry}^{2}\right)=0,5041$, yang berarti variable Denyut Nadi Istirahat memberikan sumbangan terhadap Kapasitas Aerobik sebesar 50,41\%. Ketiga, terdapat hubungan yang signifikan antara Kadar Hemoglobin dan Denyut Nadi Istirahat secara bersama-sama terhadap Kapasitas Aerobik dengan persamaan garis regresi linear ganda $\tilde{Y}=3,5+0,44 \mathrm{X} 1+0,49 \mathrm{X} 2$, koefisien korelasi ganda $(\mathrm{Ry} 1-2)=$ 0,81 dan koefisien determinasi $\left(\right.$ Ry1- $\left.^{2}\right)=0,6561$, yang berarti bahwa variabel Kadar Hemoglobin dan Denyut Nadi Istirahat secara bersamasama memberikan sumbangan terhadap Kapasitas Aerobik sebesar 65,61\%.

Kata kunci: Kadar haemoglobin, denyut nadi istirahat, kapasitas aerobik, ekstrakurikuler futsal.
\end{abstract}

\section{PENDAHULUAN}

FUTSAL (Futbol Sala) dalam bahasa Spanyol berarti sepak bola dalam ruangan, merupakan permainan sepak bola yang dilakukan dalam ruangan. Dalam beberapa tahun ini, FUTSAL sangat marak di Indonesia, baik di Jakarta maupun di daerah. Permainan ini sendiri dilakukan oleh lima orang pemain setiap tim berbeda dengan sepak bola konvensional yang pemainnya berjumlah 
sebelas orang setiap tim. Ukuran lapangan dan ukuran bolanya pun lebih kecil dibandingkan ukuran yang digunakan dalam sepak bola lapangan rumput. Aturan permainannya pun tidak sama dengan sepak bola. Aturan permainan dalam olahraga FUTSAL dibuat sedemikian ketat oleh FIFA agar permainan ini berjalan dengan fair play dan juga sekaligus untuk sekaigus untuk menghindari cedera yang dapat terjadi. Ini disebabkan lapangan yang digunakan untuk pertandingan internasional bukan dari rumput, tetapi dari kayu atau rubber/plastik.

FUTSAL adalah permainan yang sangat cepat dan dinamis. Dari segi lapangan yang relatif kecil, hampir tidak ada ruangan untuk membuat kesalahan. Oleh karena itu, diperlukan kerja sama antara pemain lewat passing yang akurat, bukan hanya untuk melewati lawan. Ini disebabkan dalam permainan FUTSAL pemain selalu berangkat dengan falsafah $100 \%$ ball possession. Akan tetapi, melalui timing dan positioning yang tepat, bola dari lawan akan direbut kembali.

FUTSAL adalah olahraga beregu. Kolektifitas tinggi akan mengangkat prestasi. Siapa yang mencetak gol sama sekali tidak penting. Yang penting adalah gol yang dicetak. Menang dan kalah itu terjadi di seluruh olahraga, tetapi if you die, you die with honour. Tidak ada pemain yang paling berjasa dalam satu tim, yang ada adalah tim yang baik akan menjadikan seorang pemain menjadi bintang.

Dengan ukuran lapangan yang lebih kecil dan jumlah pemain yang lebih sedikit maka setiap pemain FUTSAL dituntut untuk memiliki tingkat kesegaran jasmani yang baik. Ksegaran jasmani sendiri sangat berhubungan dengan kesehatan, seperti : Daya tahan jantung paru (kardiorespirasi), kekuatan otot, daya tahan otot, fleksibilitas dan komposisi tubuh. Dari beberapa komponen kesegaran jasmani, daya tahan jantung paru memiliki peran penting untuk meningkatkan kesegaran jasmani. Dan dalam peningkatan kesegaran jasmani dibutuhkan kadar hemoglobin yang baik di

dalam aliran darah, untuk transportasi oksigen. Semakin tinggi kesegaran jasmani atlet FUTSAL akan memiliki kapasitas aerobik yang baik. Dan dalam melakukan aktifitas sehari-hari tidak akan mengalami kelelahan yang berarti. Tanda tersebut, dapat ditentukan dengan mengetahui denyut nadi. Perlu diketahui bahwa untuk mencapai tingkat kesegaran jasmani yang baik, dibutuhkan faktor lain yang menunjang.

Faktor lain yang menunjang adalah keseimbangan akan bahan-bahan makanan seperti : Karbohidrat, protein, lemak dan zat-zat mineral lainnya. Begitu penting tingkat kesegaran jasmani seorang atlet FUTSAL, penulis tertarik untuk mengadakan suatu penelitian komponenkomponen kesegaran jasmani yang berhubungan secara langsung seperti kapasitas aerobik, dan secara tidak langsung seperti denyut nadi dengan kadar hemoglobin di dalam darah.

Adapun alasan penulis untuk mengadakan suatu penelitian tentang kadar hemoglobin dan denyut nadi adalah karena kedua komponen tersebut memegang peran penting dalam penentuan kapasitas aerobik. Penulis berharap penelitian ini dapat memberikan sumbangan yang berarti bagi perkembangan FUTSAL di SMKN 58 Jakarta pada khususnya dan dunia olahragapada umumnya.

Tinjauan Pustaka. Di dalam tubuh manusia memiliki banyak jaringanjaringan yang aktif bekerja. Untuk menjalankan aktifitasnya dibutuhkan sejumlah energi. Sejumlah energi tersebut, diperoleh dari sumber sari-sari makanan yang telah diserap oleh sel-sel tubuh dengan proses pembakaran. Pada proses pembakaran sari-sari makanan di sel-sel tubuh dibutuhkan oksigen yang berasal dari lingkungan. Jadi oksigen sangat berperan penting untuk 
kelangsungan hidup manusia. Jumlah oksigen di dalam tubuh adalah sebagai tolak ukur terhadap tingkat kesegaran jasmani seseorang.

Apabila tingkat kesegaran jasmani seseorang tinggi maka akan memiliki daya tahan jantung yang baik. Daya tahan jantung merupakan kemampuan tubuh melakukan aktifitas fisik sehari-hari tanpa ada rasa kelelahan yang berarti. Istilah daya tahan jantung sering disebut daya tahan kardiorespirasi. Kapasitas aerobik atau Cardio Respiratory Endurance ialah suatu kualitas yang memungkinkan kita mampu melaksanakan terus menerus selama mungkin suatu kerja fisik yang agar bersifat umum dalam kondisi aerobic (cukup oksigen).

Dari uraian diatas, setiap aktifitas fisik yang terus menerus dalam waktu lama, jelas membutuhkan tingkat kesegaran jasmani yang baik. Latihan fisik yang rutin akan meningkatkan daya tahan jantung dan sekaligus kesegaran jasmani. Daya tahan kardiovaskuler merupakan faktor utama dalam kesegaran jasmani, bahkan sering jadi sinonim. Dalam laboraturium, pengukuran yang paling obyektif dilakukan dengan menghitung ambilan maksimal O2 ( $\mathrm{VO} 2$ $\max$ ).

Jadi jelas bahwa untuk melaksanakan suatu kerja fisik dibutuhkan kondisi tubuh yang cukup oksigen. Semakin tinggi kapasitas aerobiknya, maka untuk melaksanakan aktifitas seharihari tidak akan mengalami kelelahan yang berarti. Faktor fisiologis yang mempengaruhi kapasitas aerobik adalah keturunan, usia, jenis kelamin dan aktifitas fisik. Dan sekali lagi latihan sangat akan membedakan tingkat kapasitas aerobik seseorang dengan orang yang lainnya.

Sedangkan menurut Pate Russel ukuran kapasitas aerobik maksimal (VO2 Max) relatif, dikarenakan antara yang satu dengan yang lain tidak memiliki kemampuan kapasitas aerobik maksimal (VO2 Max) yang sama, dimana nilai tersebut bervariasi antara kurang 6 $\mathrm{ml} / \mathrm{kg} / \mathrm{menit}$ sampai lebih $80 \mathrm{ml} / \mathrm{kg} /$ menit. Namun pada umumnya yang mempengaruhi dan membatasi kapasitas aerobik maksimal (VO2 Max) faktor fisiologis yang terdiri dari :

a. Fungsi jantung dan paru-paru

b. Metabolisme otot aerobic

c. Kegemukan badan

d. Keadaan latihan

Maka dapat disimpulkan dari uraian-uraian di atas bahwa seseorang yang satu dengan orang lainnya mempunyai kapasitas aerobik yang berbeda-beda. Dapat dilihat dari banyak faktor seperti, keturunan, jenis kelamin, asupan gizi, kegiatan sehari-hari dll. Jadi perlu dilakukan pengukuran untuk menentukan kapasitas aerobik seseorang.

Haemoglobin. Pada semua mahluk hidup memiliki suatu sistem atau proses untuk mempertahankan kelangsungan hidupnya. Suatu sistem atau proses yang dimiliki mahluk hidup ada yang disebut sistem sirkulasi. Mahluk hidup yang memiliki jaringan atau sel-sel tubuh yang aktif membutuhkan sistem yang mengangkut sari-sari makanan. Pada manusia sistem sirkulasi sangat dibutuhkan untuk mengangkut sari-sari makanan dan meyebarkan ke sel-sel tubuh. Sistem sirkulasi tersebut memiliki komponen yang disebut sel darah.

Dalam buku Ilmu Faal Dasar menjelaskan darah (hemo) adalah sistem cair yang mengalir sepanjang pembuluh darah tertutup (mulai dari jantung, berakhir di jantung). Jumlah/Volume darah dalam tubuh manusia antara 1/12-1/13 (5-9\%) berat badan pada pria sekitar $5 \mathrm{lt}$, pada wanita sekitar 4,5 lt. Fungsi darah secara umum dapat dibedakan sbb :

1. Alat pengangkut, yang di angkut antara lain :

a. Zat makanan (nutrisi), dari system pencernaan makanan (digetivus) ke sel-sel.

b. $\mathrm{O} 2$ dari paru-paru ke sel, dan $\mathrm{CO} 2$ dari sel ke paru-paru. 
c. Sampah metabolisme sel, dari sel ke alat-alat ekresi.

d. Panas dari bagian yang aktif ke seluruh tubuh.

2. Mempertahankan kadar asam dan basa cairan tubuh.

3. Reaksi immunologi/kekebalan tubuh.

Dari uraian tersebut, peredaran darah utama adalah jantung memompa dimulai dari ventrikel kiri masuk keseluruh tubuh, kemudian kembali ke jantung melalui atrium kanan. Sedangkan peredaran darah paru- paru adalah jantung memompa dari ventrikel kanan masuk ke paru-paru kembali ke jantung melalui atrium kiri.

Darah memiliki peran sangat penting dalam sistem sirkulasi sebagai salah satu contoh mengedarkan sari-sari makanan dan sebagai alat transportasi oksigen. Di dalam sel darah terdapat beberapa komponen darah dan fungsinya masingmasing.

Darah terdiri benda cair yang disebut plasma darah dan benda padat yang disebut sel-sel darah, yaitu sel darah merah (Erythrocyte/Trombosit). Sel darah putih (Leucocyte/Leukosit) dan kepingkeping sel (Trombocyte/Trombosit).

Sel darah merah mampu mengikat oksigen dikarenakan mengandung suatu zat hemoglobin. Menurut istilah hemoglobin berasal dari sebuah kata yakni: "hemo" atau pemberi warna zat pemberi warna merah dan protein "globin". Kemudian kedua komponen tersebut bergabung menjadi hemoglobin. Menurut buku penuntun praktikum faal dasar dijelaskan, hemoglobin (HB) merupakan zat berwarna merah pembawa oksigen dan karbondioksida yang terdapat didalam sel darah merah. $\mathrm{Hb}$ merupakan suatu gugus protein yang mengandung Ferro (besi). Tiap gram $\mathrm{Hb}$ mengandung $1,34 \mathrm{ml}$ oksigen, konsentrasi $\mathrm{Hb}$ dalam darah kira-kira 15 gr\% (pada wanita 14 gr\% dan pria $16 \mathrm{gr} \%$ ). Ini artinya di dalam $100 \mathrm{cc}$ darah mengandung $15 \mathrm{gr} \mathrm{Hb}$ atau 15 kali $1,34 \mathrm{ml}$ oksigen yang berikatkan dengan $\mathrm{Hb}$.
Dari uraian diatas, menyatakan bahwa hemoglobin adalah zat terpenting dalam sel darah merah, kadar antara pria dan wanita berbeda. Kadar hemoglobin di dalam sel darah merah sangat penting untuk mengikat oksigen dan menyebarkan ke seluruh sel-sel tubuh. Hemoglobin merupakan gabungan antara protein dan pemberi zat warna merah pada darah. Pada sel darah merah yang semakin pekat warna merahnya menunjukan kandungan oksigen di dalam sel darah merah semakin banyak.

Ganong menjelaskan perubahan fungsi jantung dengan berolahraga, menyebabkan frekuensi denyut jantung ke nilai tinggi, yaitu :

\section{Tabel 1. Perubahan Fungsi Jantung} Dengan Berolahraga

\begin{tabular}{c|c|c}
$\begin{array}{c}\text { Kerja } \\
\text { (kg-m/menit) }\end{array}$ & $\begin{array}{c}\text { Penggunaa O2 } \\
\text { (ml/menit) }\end{array}$ & $\begin{array}{c}\text { Denyut } \\
\text { Jantung } \\
\text { (per menit) }\end{array}$ \\
\hline Istirahat & 267 & 64 \\
288 & 910 & 104 \\
540 & 1430 & 122 \\
900 & 2143 & 161 \\
1260 & 3007 & 173
\end{tabular}

Dari penjelasan di atas, frekuensi jantung akan meningkat ketika tubuh sedang melakukan kerja, karena membutuhkan oksigen, dan pada keadaan istirahat, penggunaan oksigen tidak terlalu banyak sehingga denyut jantung pada keadaan normal.

Kemudian Ganong menambahkan dalam bukunya Fisiologi kedokteran, $p H$ darah turun saat latihan, menyebabkan ketertarikan hemoglobin untuk mengikat oksigen. Dapat dijelaskan bahwa oksigen yang diikat oleh hemoglobin dalam darah dipengaruhi konsentrasi karbon dioksida, suhu $p H$ yang akan digunakan untuk kerja sel-sel tubuh. Jadi hemoglobin sangat dibutuhkan untuk transportasi oksigen ke sel tubuh yang membutuhkan oksigen untuk melakukan aktivitas jasmani.

Dari banyak pernyataan-pernyataan diatas, bisa disimpulkan bahwa kadar hemoglobin bisa sangat mempengaruhi kegiatan seseorang, karena jika seseorang memiliki kadar hemoglobin 
yang bagus maka daya ikat oksigen untuk mengalirkan keseluruh tubuh akan bagus pula yang mengakibatkan seseorang tersebut dapat melakukan aktifitas sehari-hari tanpa mengalami kelelahan yang berarti.

Denyut Nadi Istirahat. Setiap manusia memiliki organ jantung, pada waktu lari atau melakukan aktifitas jasmani yang berat, jantung terasa berdebar-debar. Jantung berdebar-debar bila terkejut, menghadapi suatu atau sedang emosi. Adanya detak jantung dipakai sebagai tanda seseorang masih hidup. Frekuensi denyut nadi pada umumnya sama dengan frekuensi jantung.

Dengan demikian seseorang dalam keadaan istirahat atau tidak sedang melakukan aktifitas jasmani, kerja jantungnya lebih ringan. Ini menunjukan frekuensi nadinya tidak meningkat atau dalam keadaan normal.

Pada orang dewasa normal tidak terlatih denyut nadi istirahat berkisar antara 60-80 denyut setiap menit. Sedangkan untuk orang terlatih daya tahan jantung parunya, memiliki denyut nadi istirahat lebih rendah. Karena orang terlatih mempunyai pompa jantung tiap denyutnya (stroke volume) yang lambat dengan isi banyak, menggambarkan pekerjaan jantung yang efisien. Orang yang sedang melakukan aktifitas jasmani, kerja jantung lebih rendah. Sehingga frekuensi nadi dan stroke volume dapat meningkat dari keadaan normal. Lebih lanjut menurut Arie S. Sutopo dalam buku penuntun praktikum ilmu faal dasar, denyut nadi adalah suatu denyut yang dihasilkan pompa jantung (ventrikel sinistra) untuk mengalirkan darah dan masuk ke dalam sistem arteri. Denyut nadi istirahat adalah denyut nadi yang diukur tidak dalam keadaan latihan, atau sebelum melakukan latihan. Serta dapat dilakukan pada waktu pagi hari setelah bangun tidur dan belum melakukan kegiatan apapun.
Sumber lain menjelaskan pengukuran denyut nadi istirahat yaitu denyut nadi istirahat dihitung dipagi hari sebelum bangun dari tempat tidur. Denyut nadi istirahat dapat diraba dibeberapa tempat permukaan kulit. Dan lebih baik denyut nadi istirahat diukur pada pagi hari sebelum bangun dari tempat tidur. Pengukuran denyut nadi dapat dilakukan sendiri dan dengan menggunakan alat yaitu Pulse Meter. Serta oleh para ahli seperti pelatih, perawat, dokter dan lainlain. Tempat-tempat tertentu yang diukur untuk denyut nadi dijelaskan oleh Depdiknas sebagi berikut :

a. Dipergelangan tangan depan atas pangkal ibu jari tangan (arteri radialis)

b. Dileher sebelah kiri atau kanan depan otot sterno cleidomastoideus (arteri temporalis)

c. Di dada sebelah kiri, tepat apex jantung (arteri temporalis)

d. Di pelipis

Beberapa cara pengukuran denyut nadi tersebut, merupakan parameter yang paling banyak digunakan di lapangan maupun laboraturium. Hasil pengukuran denyut nadi dapat digunakan evaluasi sistem kerja jantung pada aktifitas fisik atau kegiatan jasmani.

Dapat disimpulkan bahwa pengukuran denyut nadi sangatlah penting terutama bagi seseorang yang sedang berlatih atau berolahraga agar dapat mengetahui zona latihan mereka masing-masing, sebab zona latihan antara seorang dengan orang lainnya berbeda dan yang membedakan adalah umur dan jenis kelamin. Yang di maksud dengan zona latihan adalah tingkat intensitas dimana anda bisa berolahraga $72 \%-87 \%$ dari denyut nadi maksimal.

Futsal. FUTSAL adalah permainan bola yang dimainkan oleh dua tim, yang masing-masing beranggotakan lima orang. Tujuannya adalah memasukkan bola ke gawang lawan, dengan memanipulasi bola dengan kaki. Selain lima pemain utama, setiap regu juga diizinkan memiliki 
pemain cadangan. Tidak seperti permainan sepak bola dalam ruangan lainnya, lapangan FUTSAL dibatasi garis, bukan net atau papan. FUTSAL turut juga dikenali dengan berbagai nama lain. Istilah "FUTSAL" adalah istilah internasionalnya, berasal dari kata Spanyol atau Portugis, futbol dan sala. FUTSAL dipopulerkan di Montevideo, Uruguay pada tahun 1930, oleh Juan Carlos Ceriani. Keunikan FUTSAL mendapat perhatian di seluruh Amerika Selatan, terutamanya di Brasil. Ketrampilan yang dikembangkan dalam permainan ini dapat dilihat dalam gaya terkenal dunia yang diperlihatkan pemain-pemain Brasil di luar ruangan, pada lapangan berukuran biasa. Pele, bintang terkenal Brasil, contohnya, mengembangkan bakatnya di FUTSAL. Sementara Brasil terus menjadi pusat FUTSAL dunia, permainan ini sekarang dimainkan di bawah perlindungan Fédération Internationale de Football Association di seluruh dunia, dari Eropa hingga Amerika Tengah dan Amerika Utara serta Afrika, Asia, dan Oseania.

Pertandingan internasional pertama diadakan pada tahun 1965, Paraguay menjuarai Piala Amerika Selatan pertama. Enam perebutan Piala Amerika Selatan berikutnya diselenggarakan hingga tahun 1979, dan semua gelaran juara disapu habis Brasil. Brasil meneruskan dominasinya dengan meraih Piala Pan Amerika pertama tahun 1980 dan memenangkannya lagi pada perebutan berikutnya tahun pd 1984 .

Kejuaraan Dunia FUTSAL pertama diadakan atas bantuan FIFUSA (sebelum anggota-anggotanya bergabung dengan FIFA pada tahun 1989) di Sao Paulo, Brasil, tahun 1982, berakhir dengan Brasil di posisi pertama. Brasil mengulangi kemenangannya di Kejuaraan Dunia kedua tahun 1985 di Spanyol, tetapi menderita kekalahan dari Paraguay dalam Kejuaraan Dunia ketiga tahun 1988 di Australia.

FUTSAL adalah olahraga yang menuntut mempunyai kapasitas aerobik yang baik, karena olahraga FUTSAL dimainkan dengan 5 pemain di dalam lapangan dan di mainkan dengan cepat dan hampir tidak ada waktu untuk jalan atau diam untuk beristirahat.

Tiap atlet FUTSAL yang tergabung dalam Pelatihan nasional di haruskan memiliki VO2 MAX pada kisaran 48 hingga $50 \mathrm{ml} / \mathrm{kg} / \mathrm{menit}$. Jika tidak mencapai maka akan diberi program latihan tambahan.

Kerangka Berpikir. Kesanggupan atau kemampuan tubuh untuk melakukan penyesuaian terhadap pembebanan fisik tanpa menimbulkan kelelahan adalah tingkat kesegaran jasmani. Salah satu faktor utama dari tingkat kesegaran jasmani adalah daya tahan jantung atau kapasitas aerobik. Untuk mengetahui tingkat daya tahan jantung yang paling obyektif adalah dengan mengukur tingkat $\mathrm{VO}_{2} \max$ VO2 $\max$ adalah kemampuan tubuh secara maksimum untuk memasukkan dan menggunakan oksigen dibutuhkan kadar hemoglobin yang baik. Hemoglobin adalah suatu zat protein yang terdapat di sel darah merah yang berfungsi untuk transportasi oksigen. Oksigen yang diserap akan digunakan untuk proses pembakaran sehingga menghasikan energi. Energi yang di hasilkan sebelumnya melalui proses yang dinamakan peristiwa pengaliran darah. Darah yang datang dari seluruh tubuh melalui vena cava 9 superior dan interior) masuk kedalam ventrikel kanan melewati katup tricuspidalis. Selanjutnya ventrikel kanan berkontraksi, yang mengakibatkan darah terdorong masuk kedalam arteria pulmonalis melewati katup (valve) pulmonalis sampai ke kapiler disekitar paru-paru. Dan berdifusi di paru-paru, disinilah terjadi pertukaran darah bersih dan kotor. Selanjutnya darah akan mengalir melalui vena pulmonalis dan masuk ke atrium kiri kemudian melewati katup mitralis masuk ke ventrikel kiri. Selanjutnya darah di pompa keluar jantung mengalir melewati 
katup aortik masuk ke pembuluh darah aorta, arteria, arteriole dan kapiler (seluruh tubuh). Lalu kembali menuju jantung melalui venulae, vena, vena cava.

Dan sumber energi yang dihasilkan dari sari-sari makanan dibakar di dalam sel-sel tubuh dengan bantuan oksigen. Semakin banyak oksigen yang diserap oleh tubuh menunjukan tingkat kemampuan kapasitas aerobiknya tinggi. Dengan banyaknya oksigen dalam tubuh dibutuhkan kadar hemoglobin yang cukup, untuk mengangkut oksigen ke selsel tubuh yang membutuhkan, sehingga tetap menjalankan aktifitas fisik.

Maka kemampuan hemoglobin untuk bersenyawa dengan oksigen, tergantung dari kemampuan heme secara maksimal berkaitan dengan satu molekul oksigen. Sehingga satu molekul hemoglobin secara maksimal bersenyawa dengan empat molekul oksigen. Dapat dijelaskan kemampuan hemoglobin yang berkaitan dengan oksigen secara maksimal adalah dengan 4 molekul oksigen. Nilai normal hemoglobin untuk pria dewasa adalah $12,5-16 \mathrm{~g} / \mathrm{dl}$ dan untuk wanita dewasa adalah 11,5 - 14,5 g/dl. Diduga semakin banyak kandungan hemoglobin di dalam sel darah merah, maka semakin banyak oksigen yang dapat diangkut. Sehingga kapasitas aerobiknya meningkat.

Hubungan Denyut Nadi Istirahat dengan Kapasitas Aerobik. Tiap kegiatan jasmani atau latihan secara rutin menimbulkan perubahan terhadap kemampuan tubuh. Beban latihan yang diberikan dengan meningkatkan frekuensi latihan, lama latihan, dan berat beban akan memberikan perubahan kemampuan tubuh. Namun perlu diketahui, berat latihan merupakan intensitas latihan. Sedangkan intensitas latihan memiliki parameter yaitu dengan mengetahui frekuensi denyut nadi.

Pada orang terlatih atau olahragawan, saat istirahat denyut jantungnya lebih rendah dari orang tidak terlatih. Pada altet endurance yang terlatih baik (pembalap sepeda, pelari marathon) denyut nadi saat istirahat tercatat berada antara 40-50 detak per menit. Dapat dijelaskan, pada orang terlatih kapasitas aerobik atau endurance akan memiliki pompa jantung setiap denyut atau stroke volume yang efisien, sehingga menurunkan frekuensi denyut nadi istirahat.

Jumlah darah yang dipompakan jantung setiap menit atau Cardiac Output sebesar frekuensi denyut nadi per menit di kali Stroke Volume Jadi pada orang terlatih denyut nadi istirahatnya rendah, karena memiliki Stroke Volume yang efisien. Keadaan ini menunjukan efesiensi sistem kerja jantung pada orang terlatih. Setiap denyut jantung dapat memompa sejumlah darah yang mengandung oksigen dengan cukup untuk kebutuhan sel-sel tubuh. Diduga kapasitas aerobik tinggi, maka denyut nadi saat istirahat sangat rendah. Dan kapasitas aerobiknya rendah, maka denyut nadi saat istirahat tinggi.

Hubungan Kadar Haemoglobin dengan Denyut Nadi Istirahat. Pada saat tubuh melakukan aktifitas jasmani, peredaran darahpun akan meningkat. Kadar hemoglobin di dalam sel darah merah melandasi peran penting dalam melakukan aktifitas jasmani. Karena pada saat sel-sel di dalam tubuh membutuhkan oksigen yang akan diangkut oleh hemoglobin. Sedangkan frekuensi denyut nadi istirahat yang rendah memperlihatkan efisiensi kerja jantung.

Dampak keadaan ini menggambarkan jantung memompa darah yang mengandung oksigen ke sel-sel tubuh yang aktif bekerja mencukupi. Peningkatan volume darah dan jumlah sel darah merah akan terjadi pula, yang berarti bertambahnya kapasitas darah dalam membawa oksigen (oxygen carrying capacity).

Dapat dijelaskan bahwa tubuh yang memiliki efisiensi kerja jantung atau frekuensi kerja jantung istirahatnya rendah akan lebih efektif menghasilkan Stroke Volume atau pompa darah yang banyak. Semakin banyak darah yang dipompa akan bertambah pula oksigen 
yang diangkut hemoglobin untuk kebutuhan sel-sel tubuh yang aktif bekerja. Dan kapasitas aerobik merupakan jumlah oksigen yang diserap oleh sel-sel tubuh, serta akan diangkut dengan kadar hemoglobin di dalam sel darah merah. Kemudian jantung berdenyut untuk memompa darah yang mengandung hemoglobin yang mengikat oksigen, untuk disebarkan ke sel- sel tubuh yang membutuhkan.

Berdasarkan uraian kerangka berpikir, diduga bahwa hubungan antara kadar hemoglobin dalam darah dan denyut nadi istirahat terhadap kapsitas aerobik memiliki hubungan. Kadar hemoglobin di dalam sel darah merah dan denyut nadi istirahat bersama-sama menentukan kapasitas aerobik.

\section{METODE}

Berdasarkan rumusan masalah, penelitian ini bertujuan untuk mengetahui:

1. Hubungan antara kadar hemoglobin dengan kapasitas aerobik siswa SMKN 58 Jakarta yang mengikuti ekstrakurikuler FUTSAL.

2. Hubungan antara denyut nadi istirahat dengan kapasitas aerobik siswa SMKN 58 Jakarta yang mengikuti ekstrakurikuler FUTSAL.

3. Hubungan antara kadar hemoglobin dan denyut nadi istirahat secara bersama-sama terhadap Kapasitas Aerobik siswa SMKN 58 Jakarta yang mengikuti ekstrakurikuler FUTSAL.

Instrumen Penelitian. Data dikumpulkan dengan melakukan beberapa tes atau pengukuran:

1. Pengukuran kadar hemoglobin dengan membawa sampel ke labolatorium.

2. Pengukuran denyut nadi isirahat dengan menggunakan metode Palspasi pada arteri radialis dengan menggunakan alat : stopwatch atau jam.

3. Pengukuran kapasitas aerobik dilakukan dengan menggunakan metode Bleep Test dengan alat : lintasan datar dan tidak licin, meteran, kaset, soud system, kerucut/patok.

Teknik Pengumpulan Data. Sesuai dengan variabel yang disusun dalam penelitian, maka fasilitas dan alat untuk pengumpulan data adalah sebagai berikut:

1. Membagikan formulir data diri.

2. Sampel melakukan pengambilan darah di labolaturium untuk mengetahui kadar hemoglobin.

3. Untuk denyut nadi sampel mengisi sendiri formulir data diri

Persiapan mengukur denyut nadi :

a. Dilakukan pagi hari setelah sampel bangun tidur.

b. Dengan mengunakan palpasi pada arteri radialis

c. Menempel dan menekan tiga jari (telunjuk, tengah, manis) salah satu tangan pada pergelangan tangan yang lain.

d. Lakukan penghitungan denyut dengan stop watch dalam waktu satu menit.

e. Setelah di dapat denyut nadi maka sampel menulis di formulir yang telah dibagikan.

4. Setelah diisi oleh sampel formulir dikumpulkan, dan meneruskan observasi untuk mencari data selanjutnya.

5. Sampel melakukan bleep tes.

Persiapan bleep tes :

1. Panjang lapangan yang standar/baku adalah 20 meter dengan ukuran tiap lintasan antara 1 s.d 1,5 meter.

2. Sampel berada dalam keadaan sehat untuk melakukan tes.

3. Sampel melakukan pemanasan dengan peregangan serta menggerakan anggota tubuh terutama tungkai.

4. Sampel tidak diperbolehkan makan 2 jam sebelum tes.

5. Gunakan pakaian olahraga yang tipis dan menyerap keringat. 
6. Sampel tidak diperbolehkan merokok atau meminum minuman berakohol sebelum melakukan tes.

7. Sampel tidak boleh melakukan tes sesudah melakukan latihan berat.

Prosedur pengukuran :

1. Cek bahwa bunyi dua "bleep" yang menjadi standar untuk pengukuran lapangan adalah satu menit (60 detik). b. Sampel berada dalam keadaan sehat.

2. Sampel melakukan pemanasan.

3. Sampel harus berlari dan menyentuh/ menginjak salah satu kaki pada garis dan berputar (pivot) untuk kembali berlari setelah bunyi bleep terdengar (tunggu sampai bunyi bleep terdengar).

4. Lari bolak-balik terdiri dari beberapa tingkatan. Setiap tingkatan terdiri dari beberapa balikan. Setiap balikan ditandai dengan bunyi bleep sebanyak tiga kali, sedangkan setiap balikan ditandai satu kali bunyi bleep.

5. Sampel dianggap tidak mampu apabila dua kali berturut-turut tidak dapat menyentuh/menginjak kakinya pada garis.

6. Lakukan dengan sungguh-sungguh.

7. Untuk mempermudah memantau sampel, gunakan format terlampir.

8. Lakukan pendinginan setelah selesai tes. Jangan langsung duduk.

9. Setelah diobservasi data yang diperoleh siap untuk diolah.

\section{HASIL DAN PEMBAHASAN}

Deskripsi Data. Deskripsi data dimaksudkan untuk memperoleh gambaran tentang penyebaran data yang meliputi nilai tertinggi, nilai terendah, nilai rata-rata, simpangan baku, median, modus, varians, distribusi frekuensi, serta histogram dari masing-masing variabel $\mathrm{X} 1$, X2 maupun Y. Berikut data lengkapnya:

\section{Tabel 2. Deskripsi Data Penelitian}

\begin{tabular}{|c|c|c|c|}
\hline Variabel & $\begin{array}{c}\text { Kadar } \\
\text { Hemoglobin }\end{array}$ & $\begin{array}{c}\text { DN } \\
\text { Istirahat }\end{array}$ & $\begin{array}{c}\text { Kapasitas } \\
\text { Aerobik }\end{array}$ \\
\hline Nilai Tertinggi & 15,6 & 78 & 47,1 \\
\hline Nilai Terendah & 13,3 & 62 & 30,2 \\
\hline Rata - rata & 14,38 & 70,44 & 39,67 \\
\hline Simpangan Baku & 0,62 & 4,68 & 5,33 \\
\hline Median & 14,3 & 71 & 40,8 \\
\hline Varians & 0,39 & 21,91 & 28,47 \\
\hline
\end{tabular}

1. Variabel kadar Haemoglobin

Hasil penelitian menunjukkan rentang skor kadar haemoglobin (X1) adalah antara 13,3 sampai dengan 15,6 , nilai rata-rata sebesar 14,38, simpangan baku sebesar 0,62, median sebesar 14,3, distribusi frekuensi dapat dilihat pada tabel 3 dibawah ini:

Tabel 3. Distribusi Frekuensi Kadar Hemoglobin

\begin{tabular}{|c|c|c|c|c|}
\hline \multirow[b]{2}{*}{ No } & \multirow{2}{*}{$\begin{array}{c}\text { Interval } \\
\text { Kelas }\end{array}$} & \multicolumn{2}{|c|}{ Frekuensi } & \multirow{2}{*}{$\begin{array}{c}\text { Nilai } \\
\text { Tengah }\end{array}$} \\
\hline & & Absolut & Relatif & \\
\hline 1 & $13,30-3,76$ & 3 & 16,67 & 13,50 \\
\hline 2 & $13,77-14,23$ & 4 & 22,22 & 13,96 \\
\hline 3 & $14,24-14,70$ & 7 & 38,89 & 14,47 \\
\hline 4 & $14,71-15,17$ & 1 & 5,55 & 14,94 \\
\hline 5 & $15,18-15,64$ & 3 & 16,67 & 15,41 \\
\hline \multicolumn{2}{|c|}{ Jumlah } & 18 & 100 & \\
\hline
\end{tabular}

Berdasarkan tabel 3 diatas dibandingkan dengan nilai rata-rata, terlihat testee yang berada pada kelas rata-rata sebanyak 7 testee $(38,89 \%)$ dan yang berada di bawah rata- rata sebanyak 7 testee $(38,89 \%)$, sedangkan testee yang berada di atas ratarata kelas sebanyak 4 testee (22,22\%).

2. Variabel Denyut Nadi Istirahat

Hasil penelitian menunjukkn rentang skor denyut nadi istirahat (X2) adalah antara 6278 , nilai rata-rata sebesar 70,44 , simpangan baku sebesar 4,68, median sebesar 71, distribusi frekuensi dapat dilihat pada table 4 dibawah ini: 
Tabel 4. Distribusi Frekuensi Nadi Istirahat

\begin{tabular}{|c|c|c|c|c|}
\hline \multirow{2}{*}{ No } & \multirow{2}{*}{ Interval Kelas } & \multicolumn{2}{|c|}{ Frekuensi } & \multirow[t]{2}{*}{ Nilai Tengah } \\
\hline & & Absolut & Relatif & \\
\hline 1 & $62,00-65,20$ & 4 & 22,22 & 63,60 \\
\hline 2 & $65,21-68,50$ & 4 & 22,22 & 66,80 \\
\hline 3 & $68,51-71,18$ & 1 & 5,55 & 69,80 \\
\hline 4 & $71,19-75,10$ & 6 & 33,34 & 73,14 \\
\hline 5 & $75,11-78,40$ & 3 & 16,67 & 76,70 \\
\hline \multicolumn{2}{|c|}{$\frac{1}{\text { Jumlah }}$} & 18 & 100 & \\
\hline
\end{tabular}

Berdasarkan tabel 4 diatas dibandingkan dengan nilali rata-rata, terlihat testee yang berada pada kelas ratarata sebanyak 1 testee $(5,55 \%)$ dan yang berada pada kelas rata-rata sebanyak 8 testee $(44,44 \%)$, sedangkan testee yang berada diatas rata-rata kelas sebanyak 9 testee $(50,01 \%)$.

\section{Variabel Kapasitas Aerobik}

Hasil penelitian menunjukkan rentang skor kapasitas aerobic (Y) adalah antara 30,247,1, nilai rata-rata sebesar 39,67, simpangan baku sebesar 5,33, median sebesar 40,8, distribusi frekuensi dapat dilihat pada tabel 5 dibawah ini:

Tabel 5. Distribusi Frekuensi Kapasitas Aerobik

\begin{tabular}{|c|c|c|c|c|}
\hline \multirow{2}{*}{ No } & \multirow{2}{*}{ Interval Kelas } & \multicolumn{2}{|c|}{ Frekuensi } & \multirow{2}{*}{$\begin{array}{c}\text { Nilai } \\
\text { Tengah }\end{array}$} \\
\hline & & Absolut & Relatif & \\
\hline 1 & $30,20-33,58$ & 4 & 22,22 & 31,89 \\
\hline 2 & $33,59-36,97$ & 1 & 5,55 & 35,28 \\
\hline 3 & $36,98-40,36$ & 4 & 22,22 & 38,67 \\
\hline 4 & $40,37-43,75$ & 4 & 22,22 & 42,06 \\
\hline 5 & $43,76-47,14$ & 5 & 27,79 & 45,45 \\
\hline & Jumlah & 18 & 100 & \\
\hline
\end{tabular}

Berdasarkan tabel 5 diatas dibandingkan dengan nilai rata-rata, terlihat testee yang berada pada kelas rata-rata sebanyak 4 testee $(22,22 \%)$ dan yang berada di bawah rata- rata sebanyak 5 testee $(27,77 \%)$, sedangkan testee yang berada di atas rata-rata kelas sebanyak 9 testee $(50,01 \%)$.

\section{PENUTUP}

Kesimpulan. Berdasarkan analisis data dan hasil pengukuran yang dilaksanakan dalam penelitian ini maka dapat diambil kesimpulan sebagai berikut :

1. Terdapat hubungan yang signifikan antara Kadar Hemoglobin terhadap Kapasitas Aerobik.

2. Terdapat hubungan yang signifikan antara Denyut Nadi Istirahat terhadap Kapasitas Aerobik.

3. Terdapat hubungan yang signifikan antara Kadar Hemoglobin dan Denyut Nadi Istirahat terhadap Kapasitas Aerobik.

\section{Saran.}

1. Dalam menjalankan kehidupan sehari-hari, termasuk melakukan aktifitas sekolah ataupun berolah raga dibutuhkan tingkat kesegaran jasmani yang baik. Sehingga dapat melakukan aktifitas sehari-hari tanpa merasa kelelahan yang berarti. Tingkat kesegaran jasmani sangat berkaitan dengan kapasitas aerobik, yang dapat dipelihara dengan memperhatikan kadar hemoglobin dan denyut nadi isirahat. Karna semakin tinggi kapasitas aerobik seseorang makan orang tersebut akan dapat menjalankan akrifitas sehari-hari dan aktifitas fisik tanpa merasa kelelahan yang berarti. Berdasarkan dengan hal tersebut, disarakan agar siswa ataupun masyarakat pada umumnya baik didunia olahraga dapat mengerti pengukuran kadar hemoglobin, denyut nadi istirahat serta kapasitas aerobik.

2. Dari hasil penellitian ternyata hemoglobin dan denyut nadi istirahat memberikan kontribusi sebesar $65,61 \%$ terhadap kapasitas aerobik, dan 34,39\% sisanya ditentukan oleh faktor lain. Faktor lain yang dimaksud misalnya : Kapasitas Vitas Paru-paru, Isi Sekuncup (Stroke Volume), Volume Semenit (Minute Volume) dan Cardiac Out-put. Dengan ini penulis menyarankan untuk mengontrol kadar 
hemoglobin, denyut nadi istirahat serta mengkontrol asupan gizi, serta menyarankan untuk lebih luas menguji tentang factor-faktor lain yang menunjang dalam peningkatan kemampuan kapasitas aerobik.

\section{DAFTAR RUJUKAN}

Ali Muchtamadji M dan Cecep Habibudin. Ilmu Faal Dasar. Jakarta: Depdikbud,1999.

Depdiknas. Ketauhilah Tingkat Kesegaran jasmani Anda. Jakarta: Depdiknas, 2000.

Depdiknas. Pedoman dan Modul Pelatihan Kesehatan Olahraga Bagi Pelatih Olahragawan Pelajar. Jakarta: Depdiknas, 2000.

Ganong William F. Buku Ajaran Fisiologi Kedokteran. Terjemahan M. Djahuari Widjadja Kusumah. Jakarta: EGC, 1999.

Janssen Peter G.J.M. Latihan Laktat Denyut Nadi, terjemahan Peni K.S Mutalib. Jakarta: KONI DKI JAYA, 1993.

Lhaksana Justinus. Taktik dan Strategi Futsal Modern. Jakarta: Be Chamion, 2011.

Moeloek Dangsina dan Arjatmo

Tjokronegoro. Kesehatan dan Olahraga. Jakarta: FKUI, 1984.

Russel, Pate, et al. Dasar-dasar Ilmu Kepelatihan, IKIP Semarang : Semarang, 1933.

Sudjana, Teknik analisis Regresi dan Korelasi Bandung: Tarsino, 1922.

Sutopo Arie S dan Alma Permana W. Buku Penuntun Praktikum Ilmu Faal Dasar. Jakarta: FIK UNJ, 2001.

http://id.wikipedia.org/wiki/futsal http://www.totalolahraga-arenafutsal 